mation and Knowledge Quality in Retail Security Decision Making. 3rd International Conference on Knowledge Management [in English].

18. Wan, K., Alagar, V. (2014). Synthesizing datato-wisdomhierarchy for developing smart. International Conference on Fuzzy Systemsand Knowledge Discovery.
Retrieved

from

https://www.semanticscholar.org/paper/Synthesizing-

data-to-wisdom-hierarchy-for-smart-Wan-

Alagar/b9b3c25d813a057d609f8785788f1257e5592257

[in English].

\author{
Krugliy Dmitriy \\ Doctor of Technical Sciences, associate professor, \\ Department of Innovative Technologies \\ and Technical Means of Navigation, \\ Kherson State Maritime Academy, \\ 20, Ushakova Avenue, Kherson, Ukraine
}

\title{
USE OF DIKW METHODOLOGY FOR EDUCATIONAL PROPOSALS IN THE FRAMEWORK OF INNOVATIVE LEARNING IMPLEMENTATION
}

The article analyzes the possibilities of using the DIKW-model in relation to educational proposals. The analysis brings us back to understanding the concepts of "data", "information", "knowledge" and wisdom, where the goal of teaching is to obtain knowledge, and the learning process itself leads to wisdom. The definitions of these basic concepts are considered, which will prevent their misinterpretation and substitution. It will give an opportunity to develop a model of training, which in the future will form the required specialist. The structure of this model is considered, the connections between its components are highlighted, which are of paramount importance for the development of an effective educational proposal within the framework of innovative education and increase of independent work of the higher education seeker, where the role of the teacher changes. The preparedness for real life, forming the necessary competences and teaching the student as a specialist and personality become one of the primary tasks. First, to move to the concept of "learning", it is necessary to specify the definitions of "information" and "knowledge" to understand in which case the presentation of information on the subject will lead to the formation of knowledge and in which it will remain information. We understand the need to form a future specialist's "knowledge" and opportunities related to the category of "wisdom" under the introduction of the DIKW methodology in the educational environment. "Knowledge" cannot be replaced by an information flow or a data flow. This is a process of multiple processing of information, data, related knowledge and the copyright of the studied information is not an indicator of effectiveness. The indicator of effectiveness was defining as the ability to make the decision that is most appropriate in a given situation.

Keywords: DIKW-model, data, information, knowledge, wisdom, education.

Подано до редакиії 20.11.2020

УДК: 141.159 .923

DOI: https://doi.org/10.24195/2414-4665-2020-4-7

\begin{abstract}
Олена Денис, аспірант кафедри загальної педагогіки та дошкільної освіти, Дрогобииького державного педагогічного університету імені Івана Франка, вулиия Івана Франка, 24, м. Дрогобич, Україна
\end{abstract}

\section{САМОРЕГУЛЯЩЯ ОСОБИСТОСТІ ЯК ПСИХОЛОГО-ПЕДАГОГІЧНА ПРОБЛЕМА}

У статті розкрито сутність поняття «саморегуляиія» та «саморегуляція особистості». Наявний стан проблеми саморегуляиії особистості розглянуто в наступних позиціях: функцій або властивостей самоорганізованих систем; складної багаторівневої системної освіти; розвитку усвідомленої саморегуляиії в діяльності, а також ие поняття вивчалось в аспекті - «особистість-діяльність». Розглянуто наявний стан проблеми саморегуляиї особистості на основі існуючих наукових підходів таких, як: суб'єктно-діяльнісного підходу через розуміння усвідомленої саморегулячії діяльності як системно-організованого прочесу внутрішньої психічної активності людини за ініціації, побудові, підтримиі і управлінню різними видами $і$ формами довільної активності, щзо безпосередньо реалізовує досягнення изілей, які приймаються людиною; структурнофункиіонального підходу через саморегулячію довільної активності, яка характеризується як здатність суб'єкта і як процес. Значний інтерес для нашого дослідження представляють наукові конщепиії, що розвиваScience and Education, 2020, Issue 4 
лися у рамках: 1) системно-діяльнісної концепиії саморегуляції стану, в якій саморегуляція характеризується $i$ як діяльність, і як стан; 2) концепції індивідуального стилю саморегуляції довільної активності людини; 3) концепцій, щзо розвивають погляд на саморегуляцію як на ієрархічно організовану систему, в якій задіяні процеси різних рівнів індивідуальності. Проведений теоретичний аналіз проблеми становлення поняття «саморегуляція особистості» в науковій літературі різних галузей знань. Розкрито ретроспективу наукових досліджень щчодо саморегуляиії особистості: від розуміння ї̈ як найважливішого пояснювального принцииу в системному підходi, щуо трунтується на теоріях функціональних систем як здатностях й властивостях організму індивіда, до вивчення цієєї категорії як процесу й самостійної діяльності в регуляції функціонального стану. Розглянуті основні концептуальні положення та напрями досліджень, в яких сформульовано основні поняття з досліджуваної проблеми. Розкрито механізми саморегуляції особистості такі, як самооцінка, рівень власних домагань, самоконтроль, рефлексія, самостимуляція.

Ключові слова: регулячія, саморегуляція, самоорганізація, саморегулячія особистості.

\section{блеми}

Вступ та сучасний стан досліджуваної про-

На сучасному етапі розвитку суспільства набуває особливого значення необхідність формування саморегуляції особистості в процесі життєдіяльності. Адже успішна діяльність людини залежить від іï готовності до стійкого функціонування в різноманітних умовах життєдіяльності, здатності критично оцінювати свої дії, а також, на основі усвідомлення та прийняття суспільних вимог, керувати власним психічним станом й поведінкою. Особистість як самостійний суб'єкт своєї діяльності потребує на багато більше зусиль та часу для координації та регуляції власного життя незалежно від тимчасових впливів середовища. Тому саморегуляція є необхідною здатністю суб'єкта, який здійснює активну та цілеспрямовану діяльність.

Таким чином, саморегуляція як цілісна система психічних засобів, за допомогою яких людина здатна керувати своєю цілеспрямованою активністю, стає не перевагою, а життєвою необхідністю.

У психолого-педагогічній літературі розглядаються різноманітні підходи до визначення феномену саморегуляції. Основна увага науковців приділена дослідженню саморегуляції поведінки особистості (Л. Божович, М. Боришевський, В. Селіванов); емоційно-вольової сфери (В. Іванніков, М. Кузнєцов, Я. Рейковський); мотиваційно-особистісної сфери (К. Абульханова-Славська, I. Галян, О. Конопкін). Саморегуляцію як системну якість особистості досліджували О. Тихомирова, С. Максименко. В. Моросанова розглядала іiі як процес досягнення особистістю власних цілей через управління власною діяльністю.

Особистість як суб'єкт регуляції власної поведінки й активності досліджено у працях О. Оліфера, Н. Пов'якель, Т. Титаренко. Механізми саморегуляції особистості досліджували О. Конопкін, С. Тетерук, О. Прохоров.

У сучасних закордонних дослідженнях це питання розглядається як саморегуляція праці (Д. Шунк, П. Елмер, М. Бокартс, П. Пінтріх); як саморегуляція й мотивація діяльності (Б. Циммерман); як метакогнітивні аспекти дослідження саморегуляції навчальної діяльності (К. Забруцькі, Г. Шроу, К. Гриппен, К. Рес); як поведінкові, емоційні та когнітивні аспекти саморегуляції (Дж. Сан, Р. Руед) тощо.

Найбільш актуальними напрямами в дослідженні проблеми саморегуляції в контексті професійної діяльності є: системно-діяльнісна концепція саморегуля- ції функціонального стану в екстремальних умовах складної професійної діяльності (Л. Дика), відповідно якої саморегуляція розглядається як окремий вид діяльності; концепція свідомої саморегуляції довільної активності суб'єкта діяльності (О. Конопкін); концепція індивідуального стиля саморегуляції (В. Моросанова).

\section{Мета та завдання}

Мета статті полягає в аналізі вивчення теоретичних аспектів проблеми саморегуляції особистості. Для досягнення поставленої мети сформульовано наступні завдання:

- розглянути сутність понять «саморегуляція» та «саморегуляція особистості»;

- проаналізувати в науковій літературі теоретичну розробленість проблеми саморегуляції особистості.

\section{Методи дослідження}

Для визначення сутності поняття «саморегуляція особистості» здійснювався теоретичний аналіз наукових джерел, де використовувалися наступні методи: загальнонаукові (аналіз, синтез, порівняння та узагальнення); конкретно-наукові (порівняльний, проблемно-хронологічний методи та метод наукової дедукціi); та методи узагальнення - для розкриття чинників формування здатності до саморегуляції особистості в процесі її життєдіяльності.

\section{Результати}

Дослідження наукової категорії «саморегуляція» має довгу історію, впродовж якої накопичено значний обсяг теоретичних та емпіричних знань про структуру системи саморегуляції, іiі механізми, чинники, а також окремі прояви саморегуляції в різних видах діяльносTi.

У психолого-педагогічній науці немає єдиного погляду на визначення поняття «саморегуляція», оскільки цей феномен має пряме відношення до самих різних проявів самоактивності та входить до структури різних складових процесів і систем.

Своє бачення саморегуляції у руслі теорії самоорганізації розглядає Р. Абдєєв (1994), який вважає, що саморегуляція $\epsilon$ першим контуром зворотного зв'язку механізму управління. Вона забезпечує цілісність живої субстанції, іiі стійке функціонування в умовах впливу зовнішнього середовища.

Введення категорій теорії самоорганізації в науковий обіг вплинуло на формаційний підхід, що тривалий час використовувався у вітчизняній науці. Так, на думку Ю. Єршова, «тільки виходячи з єдності елементів та структури, субстратної й функціональної 
структур, класів, соціальних груп та їх суспільних відносин, ми зможемо прийти до розуміння формації як саморегулятивного цілого, в процесі руху якого виявляються можливості розвитку кожного з елементів, а в міру того, як вони реалізуються, змінюється організація системи загалом» (Сршов, 1990: 29).

Отже, сучасні наукові теорії самоорганізації дають можливість розглянути саморегуляцію як функцію або властивість самоорганізованих систем. Ця властивість (функція) тотожна регуляції і характеризує здатність системи до змін під дією зовнішніх та внутрішніх впливів і являє собою процеси впорядкування змін, що дає можливість стабілізувати саморегулятивну систему після нововведень. Дія саморегуляції (регуляції) відбувається на основі загальної властивості матерії - відображення і проходить через механізми прямого та зворотного зв'язків, а також проявляється в певних формах, притаманних лише соціальним системам - самоуправління (управління) та керівництво.

Розглядаючи саморегуляцію як функцію саморегулятивних систем, вчені спираються на більш ранні дослідження цієї проблеми, зокрема на теорію функціоналізму. Ще у XIX ст. у дослідженнях одного 3 його засновників - Г. Спенсера - розглядалися складові частини суспільства, їхня зростаюча взаємозалежність, яка породжує необхідність створення «регулюючої системи», що контролювала б дії цих частин і забезпечувала їх координацію (Осипов, 1999).

У XX ст. інший представник функціоналізму T. Парсонс виокремлював у соціальній системі інтегративні та регулятивні процеси, що мають компенсуючий характер, оскільки відновлюють стабільність системи після потрясінь та змін (Парсонс, 1998: 270).

Таким чином, представники теорії функціоналізму виокремлюють у суспільстві регулятивні процеси та систему, які забезпечують координацію та контроль системи по відношенню до оточення та окремих частин соціальної цілісності

Отже, розглянувши різні погляди на визначення цього терміну можна узагальнити, що «саморегуляція» - це процес, який допомагає керувати, налагоджувати та приводити до ладу власні фізіологічні процеси та процеси психіки.

У психолого-педагогічній науці існує багато визначень поняття «саморегуляція особистості». Так, в психологічній енциклопедії це поняття характеризується як «здатність особистості керувати собою на основі сприймання й усвідомлення власних психічних станів і поведінки» (Степанов, 2006).

У своєму дослідженні С. Тетерук розглядає саморегуляцію як цілісне особистісне утворення, що забезпечує побудову й реалізацію дій особистості згідно з поставленою метою, відповідно до якої саморегуляція полягає в усвідомленому й цілеспрямованому плануванні, побудові та відтворенні власних дій у процесі самовдосконалення (Тетерук, 2006).

У психологічному напрямку поняття «саморегуляція» має неоднозначне трактування. В. Іванніков розглядає саморегуляцію як допомогу в процесі вирішення проблеми підходу до аналізу волі через аналіз регуляції виконавчої частини дії і різних психічних процесів» (Іванніков, 1991: 140).

На думку Л. Буєвої, саморегуляція - «це переведення індивідом усередину зовнішніх регулятивних систем», тобто це «норми, принципи, зразки поведінки, ціннісні орієнтації тощо, що засвоюються людиною, перетворюючись для неї в норми її внутрішньої саморегуляції, входять в їі побут, у звички, в культуру» (Буєва, 1971: 28).

Л. Виготський вважав, що «саморегуляція соціальної життєдіяльності людини може бути адекватною цій життєдіяльності тільки здійснюючись соціальними ж засобами, що виробляються людьми, а не природою» (Виготський, 1960: 41). Таку саморегуляцію він називає «автостимуляція», тобто створення й використання штучних стимулів-засобів і визначення за їх допомогою власної поведінки.

В своєму дослідженні К. Абульханова-Славська (Абульханова-Славська, 1991) описує психічну саморегуляцію людини як здатність до організації власної активності, іiі мобілізації, регулювання, узгодження 3 об'єктивними вимогами й активністю інших людей. Вона відмічає, що в організацію діяльності входить й неусвідомлена саморегуляція активності як послідовність включення сприйняття, мислення, спосіб реалізації здібностей, темп діяльності, установка на складність тощо. При цьому суб'єкт зручним і типовим для себе чином актуалізує, перетворює, спрямовує систему власних якостей саме за допомогою механізмів саморегуляції.

Розглядаючи динамічні особливості психічної саморегуляції й активності людини, В. Русалов (Русалов, 1979) прийшов до висновку про існування ряду чинників, що значною мірою визначають стратегію поведінки в ймовірному середовищі. Один 3 них, $\epsilon$ «чинником чутливості до ймовірного середовища», що свідчить про стійку здатність людини до сприйняття певного рівня стосунків між ймовірними подіями такими, як відображення структури системи подій, недооцінку, відносно адекватну оцінку або переоцінку частоти найбільш вірогідної події.

Так, С. Рубінштейн (Рубінштейн, 1997) та його учні на прикладі мислення розвинули ідею детермінізму саморегуляції як діяльності і як процесу. Обгрунтовуючи положення про те, що детермінація як процес, що безперервно формується за допомогою універсального «механізму» мислення - аналізу через синтез, вони відкрили можливості для вивчення вищих видів активності людини. По суті C. Рубінштейном було закладено уявлення про можливості розділення процесів активності (здійснюється у формі «дії») і процесів регуляції цієї активності (регуляція «свідомістю»).

Зближення та відмінності цієї концепції з теорією функціональних систем детально розкрив О. Брушлинський (Брушлинський, 1999). Він показав, що в регуляції дій психічне бере участь в нерозривному зв'язку з фізіологічним і фізико-хімічним, а співвідношення між різними рівнями саморегуляції визначаються тим, що закономірності рівнів, що пролягають нижче, зберігають свою силу для складніших сфер буття.

У подальших дослідженнях поняття «саморегу- 
ляція» вивчалась 3 позиції «особистість-діяльність». Якщо особистісні концепції розглядають регуляцію як роботу над собою, то операційні ігнорують індивідуальну специфіку реалізації довільних процесів (Сафонова, 2010). Крім того, з'явилися теорії, що розглядають саморегуляцію як складну багаторівневу системну освіту.

Так, Ю. Миславський (Миславський, 1994) під саморегуляцією особистості розуміє як процес підтримки загальної продуктивної активності, так й процес просування людини до бажаного образу «Я».

Значний інтерес представляють концепції, що розвивалися у рамках суб'єктно-діяльнісного підходу, оскільки безпосередньою теоретичною основою для них слугувала теорія функціональних систем. У них склалося розуміння усвідомленої саморегуляції діяльності як системно-організованого процесу внутрішньої психічної активності людини за ініціації, побудові, підтримці і управлінню різними видами і формами довільної активності, що безпосередньо реалізовує досягнення цілей, які приймаються людиною.

Науковці визначають два процеси в саморегуляції діяльності, які знаходяться в тісному взаємозв'язку - особистісну регуляцію та регуляцію діяльності (Галян, 2015). Саморегуляція діяльності полягає в регулюванні суб'єктом усіх аспектів планування, організації та здійснення власної діяльності. Її предметом є дії, що спрямовані на перетворення ставлень людини до самої себе, інших людей, а також діяльності, до якої людина долучена.

Розвиваючи ідею структурно-функціонального підходу до саморегуляції довільної активності, О. Конопкін (Конопкін,1980) розглядав іiі і як здатність суб'єкта, і як процес. Він використовував уявлення про іiі усвідомленість, системність залучених регуляторних психічних функцій, а також проводив думку про злагодженість діяльності й саморегуляції, що обумовлена прийнятою суб'єктом метою.

Одним із найважливіших завдань у дослідженні проблеми саморегуляції особистості $€$ вивчення iï психологічних механізмів та виявлення їхньої взаємодії. У процесі будь-якої діяльності застосовуються такі механізми саморегуляції, як самооцінка, рівень власних домагань, самоконтроль, рефлексія, самостимуляція тощо (Тетерук, 2006).

Самооцінка в будь-якій діяльності відіграє важливу роль, оскільки виконує функцію саморегуляції, а також слугує засобом психологічного захисту особистості. Самооцінка $є$ необхідною внутрішньою передумовою саморегуляції та тісно пов'язана з процесами планування та цілепокладання.

Домагання також відіграють важливу роль в діяльності особистості, адже їх рівень базується на самооцінці, а також визначає та корегує мету й завдання в певній діяльності. Завдяки адекватному рівню домагань людина може визначити необхідну кількість власних зусиль для здійснення відповідної діяльності.

Самоконтроль допомагає особистості визначити помилки в певній діяльності та уникнути повторення в майбутньому. Оскільки успішність саморегуляції прямо залежить від самоконтролю, тому сприяє формуванню правильного образу в пам'яті та стає етало- ном у складній системі дій.

Наступний механізм саморегуляції - рефлексія, яка не тільки внутрішньо скеровує діяльність особистості, а, головне, в різних ситуаціях сприяє формуванню їі вміння приймати рішення та відповідати за них, а також усвідомлювати власні інтереси та мотиви поведінки.

Ще одним важливим механізмом саморегуляції $\epsilon$ самостимуляція, яка забезпечує мобілізацію особистісних властивостей суб' єкта для подолання труднощів, які виникають у будь-якому процесі.

Але при цьому механізми саморегуляції особистості можуть бути різними:

1) тільки внутрішні, генетично-детерміновані;

2) відносно пасивна зовнішня ланка;

3) активна зовнішня ланка саморегуляції, що включає цілеспрямовану поведінку суб'єктів у зовнішньому середовищі.

Узагальнюючи вищезазначене, можна дійти висновку, що наукові погляди на саморегуляцію розвиваються від розуміння її як найважливішого пояснювального принципу в системному підході, що грунтується на теоріях функціональних систем як здатностях й властивостях організму, до вивчення її як процесу й самостійної діяльності в регуляції функціонального стану.

Не менш важливими є концепції, що розвивають погляд на саморегуляцію як на ієрархічно організовану систему, в якій задіяні процеси різних рівнів індивідуальності (Сеіна, 2009). А в дослідженнях Л. Дикої представлена системно-діяльнісна концепція саморегуляції стану, в якій саморегуляція характеризується і як діяльність, і як стан (Дика, 2003). Враховуючи три рівні індивідуальності (енергоактиваційний, психодинамічний та особистісний), автор обгрунтовує поняття індивідуального стилю, що визначає стратегію й тактику саморегуляції функціональних станів.

У своїх дослідженнях А. Прохоров, І. Кулигіна (Прохоров, Кулигіна, 2007) підкреслюють динамічність способів регуляції функціональних станів особистості. Ці дослідження були спрямовані на виявлення відносно стійких операційних засобів та комплексів саморегуляції станів, актуалізація яких пов'язана 3 повсякденною поведінкою в контексті різних форм людського буття.

Таким чином, вимоги оптимального функціонування суб'єкта в соціальній системі при виконанні діяльності або життєдіяльності призводять до утворення і фіксації відносно стійких функціональних комплексів із різних способів і прийомів саморегуляціï.

Розвиток усвідомленої саморегуляції в діяльності пов'язаний із включенням у цей процес нових рівнів функціонування свідомості. Разом 3 рефлексією, завдяки якій власна діяльність з'являється перед суб'єктом у формі, що доступна для аналізу та оцінки, все більш важливу роль починає грати розумове утворення, яке включає навчальну діяльність, іiі процес і результат в систему індивідуального особистісного змісту. Контур саморегулювання діяльності ускладнюється, окрім параметрів саморегулювання, що задаються соціальними нормативами, з'являються вну- 
трішні, суб'єктивно значимі критерії успішності і нормативності діяльності, що породжуються ціннісно-смисловою сферою особистості. Подібно до того, як «індивідуальність знімає характер», особистісний зміст в діяльності починає функціонально домінувати над типологічними характеристиками в системі індивідуальної регуляції. Регулятивні процеси усе більш опосередкують ціннісно-смисловою сферою. Повна сформованість суб'єктної позиції у вченні визначається розвитком її трьох складових: когнітивної, регуляторної і особово-смисловий (Божович, 2001).

Така саморегуляція особистості передбачає:

- свідоме підпорядкування вчинків етичним і професійним вимогам;

- належне володіння собою, своїми емоціями, почуттями, прагненнями;

- затримку й усунення неприємних в певних ситуаціях проявів настрою і психічних станів;

- усвідомлення своїх домагань та адекватне самопізнання, що передбачає адекватну самооцінку рівня своїх знань, умінь, навичок, здібностей, досягнень особистісного розвитку, суб'єктного й професійного становлення;

- здійснення завдань професійного, особистісного й суб'єктного самовдосконалення на основі самопізнання.

Таким чином, саморегуляція особистості-це

\section{Література}

1. Абдеев Р. Ф. Философия информационной цивилизации. Москва: ВЛАДОС, 1994. 336 с.

2. Абульханова-Славская К. А. Стратегия жизни. Москва: Мысль, 1991. 299 с.

3. Божович Л. И. Проблемы формирования личности: Избранные психологические труды. 3-е изд. Под ред. Д. И. Фельдштейна. Москва: МПСИ, 2001. $352 \mathrm{c}$.

4. Брушлинский

A. B.

Субъектнодеятельностная концепция и теория функциональных систем. Вопр. психол. 1999. № 5. С. 110-121.

5. Буева Л. П. Общественная детерминация и управление формированием личности. Проблема управления процессом воспитания (материалы симпозиума). Москва, 1971. С. 28.

6. Выготский Л. С. Развитие высших психических функций. Москва: Изд. АПН, 1960. С. 41.

7. Галян І. М. Психологічний аналіз сутності саморегуляції як особистісної здатності. Збірник наукових праць: філософія, соціологія, психологія. ІваноФранківськ: Вид-во ДВНЗ «Прикарпатський національний університет імені Василя Стефаника», 2015. Вип. 20 (1). С. 154-161.

8. Дикая Л. Г. Психическая саморегуляция функционального состояния человека (системнодеятельностный подход). Москва: Изд-во Институт психологии РАН, 2003. 318 с.

9. Ершов Ю. Г. Человек. Социум. История (социально-философские проблемы теории исторического процесса). Свердловск: Изд-во Уральского университета, 1990. С. 29.

10. Иванников В. А. Психические механизмы волевой регуляции. Москва: Изд-во МГУ, 1991. 140 с. усвідомлений процес, спрямований на побудову дій та поведінки, що відповідають завданням особистісного розвитку, професійного та суб' єктного становлення у середовищі.

\section{Висновки}

На основі теоретичного аналізу нам вдалося узагальнити та систематизувати підходи до вивчення цієї проблеми, через розкриття сутності й специфіки саморегуляції особистості та визначення пї основних механізмів.

У психолого-педагогічній науці не існує єдиного загального погляду на визначення поняття «саморегуляція особистості», адже цей феномен має пряме відношення до самих різних проявів самоактивності та входить у структуру різних складових процесів і систем. Теоретичний огляд показує, що вивчення проблеми саморегуляції особистості полягає в цілеспрямованому плануванні, побудові та відтворенні суб'єктом власних дій, в умінні володіти собою, своїми емоціями та усвідомлювати свої наміри.

Таким чином, саморегуляція особистості - це процес управління людиною власними фізичними й психічними станами та вчинками, що здійснюються через зниження втоми, напруги, зняття хвилювань, зміни мотивів діяльності, підвищення стійкості до стресу та подолання нерішучості й страху.

11. История социологии в Западной Европе и США : учебник для вузов. Отв. ред. акад. РАН Г. В. Осипов. Москва: Издательская группа НОРМАИНФРА, 1999. С. 46.

12. Конопкин О. А. Психологические механизмы регуляции деятельности. Москва: Наука, 1980. 256 c.

13. Миславский Ю. А. Природа и структура системы саморегуляции и активности личности: автореф. дис. ... д-ра психол. наук. Москва: ПИРАО, 1994. 45 с.

14. Моросанова В. И. Индивидуальный стиль саморегуляции: феномен, структура и функции в произвольной активности человека. Москва: Наука. 2001. 192 c.

15. Парсонс Т. Система современных обществ. Под ред. М. С. Ковалевой (пер. с англ. Л. А. Седова и А. Д. Ковалева). Москва: Аспект Пресс, 1998. 270 с.

16. Прохоров А. О., Кулыгина И. В. Повседневный копинг: операциональные средства и комплексы саморегуляции психических состояний субъекта. Психология совладающего поведения : материалы Междунар. науч.-практ. конф. Кострома: КГУ им. Н.А. Некрасова, 2007. 426 с.

17. Психологический словарь. Под ред. А. В. Петровского, М. Г. Ярошевского. Москва, 1990. 607 с

18. Психологічна енциклопедія. авт.-упоряд. О. М. Степанов. Київ: Академвидавництво, 2006. 424 c.

19. Рубинштейн С. Л. Избранные философскопсихологические труды. Москва: Наука, 1997. 463 с.

20. Русалов В. М. Биологические основы индивидуально-психологических различий. Москва: Наука, 1979. 352 с. 
21. Сафонова Т. О. Уровневые характеристики саморегуляции личности. Вестн. КемГУ. 2010. № 3 (43). C. 100-106.

22. Сеина С. А. Проблема многоуровневого обеспечения регуляции поведения. Учёные записки. Электронный научный журнал Курского государственного университета. 2009. № 3. С. 122-128.

23. Тетерук С. П. Формування механізмів саморегуляції студентів в іншомовному просторі : автореф. дис. канд. психол. наук: 19.00.07. Київ, 2006. 21 c.

24. Schunk Dale H., Ertmer Peggy A., Boekaerts Monique (Ed.), Pintrich Paul R. (Ed), Zeidner Moshe (Ed). Self-regulation and academiclearning: Self-efficacy enhancing interventions. Handbook of self-regulation. San Diego, CA, US: Academic Press, 2000. 783 p.

25. Schraw G., Crippen K.J. \& Hartley K. Res. Promoting Self-Regulation in Science Education: Metacognition as Part of a Broader Perspective on Learning. Research in Science Education. 2006. Volume 36 (1-2). P. 111-139.

26. Sun J.C-H. \& Rueda R. Situational interest, computer selfefficacy and self-regulation: Their impact on student engagement in distance education. British Journal of Educational Technology. 2012. Volume 43 (2). P. 191204.

27. Zabrucky, K. M. Metacognition and learning. In N. Salkind (Ed.), Encyclopedia of Educational Psychology - Thousand Oaks, CA: SAGE Publications, Inc, 2008. P. 673-676.

28. Zimmermann B. Investigating Self-Regulation and Motivation: Historical Background, Methodological Developments, and Future Prospects. American Educational Research Journal. 2008. Volume 45 (1), P.166-183.

\section{References}

1. Abdeev, R. F. (1994). Fylosofiya informatsionnoi tsyvylizatsyi [Philosophy of information civilization]. Moscow: VLADOS [in Russian].

2. Abulkhanova-Slavskaia, K. A. (1991). Strategiya zhizni [Strategy of life]. Moscow: Mysl [in Russian].

3. Bozhovych, L. Y. (2001). Problemy formirovaniya lichnosti [Problems of personality formation]. D.Y. Feldshteyna (Eds). Moscow: MPSI [in Russian].

4. Brushlinskiy, A. V. (1999). Subektnodeyatelnostnaya kontseptsiya i teoriya funktsionalnyh sistem [Subject-activity concept and theory of functional systems]. Vopr. psihol. - Vopr. psychol, 5, 110-121 [in Russian].

5. Bueva, L. P. (1971). Obschestvennaya determinatsiya $i$ upravlenie formirovaniem lichnosti. Problema upravleniya protsessom vospitaniya [Social determination and management of personality formation. The problem of managing the upbringing process]. Moscow [in Russian].

6. Vyhotskiy, L. S. (1960). Razvitie vysshikh psikhicheskikh funktsii [Development of higher mental functions]. Moscow: Publishing House of APN [in Russian].
7. Galyan, I. M. (2015). Psikhologichnyi analiz sutnosti samoreguliatsii yak osobistisnoi zdatnosti [Psychological analysis of the essence of self-regulation as a personal ability]. Zbirnik naukovikh prats: filosofiya, sociologiya, psikhologiya - Collection of scientific works: philosophy, sociology, psychology, 20 (1), 154-161. Ivano-Frankivsk: Publishing House of DVNZ «Prykarpatskyi Vasylya Stefanika national university» [in Ukraine].

8. Dikaya, L. H. (2003). Psikhicheskaya samoregulyaciya funkcional'nogo sostoyaniya cheloveka (sistemno-deyatel'nostnyj podkhod) [Psychic selfregulation of the functional state of a person (systemactivity approach)]. Moscow: The Publishing House "Institute of psychology Russian academy of sciences" [in Russian].

9. Ershov, Y. H. (1990). Chelovek. Socium. Istoriya (sotsialno-filosofskie problemy teorii istoricheskogo processa) [History (socio-philosophical problems of the theory of the historical process)]. Sverdlovsk: Ural University Publishing [in Russian].

10. Ivannikov, V. A. (1991). Psikhicheskie mekhanizmy volevoi regulyatsii [Psychic mechanisms of volitional regulation]. Moscow: MHU Publishing House [in Russian].

11. Osipov, H. V. (Eds.). (1999). Istoriya sociologii v Zapadnoj Evrope $i$ USA [History of sociology in Western Europe and the United States]. Moscow: Izdatelskaia gruppa NORMA-INFRA [in Russian].

12. Konopkin, O. A. (1980). Psikhologicheskie mekhanizmy regulyatsii deyatelnosti [Psychological mechanisms of regulation of activity]. Moscow: Nauka [in Russian].

13. Mislavskiy, Y. A. (1994). Priroda i struktura sistemy samoregulyatsii i aktivnosti lichnosti [The nature and structure of the system of self-regulation and personality activity]. Extended abstract of Doctor's thesis. Moscow: PIRAO [in Russian].

14. Morosanova, V. Y. (2001). Individualny stil samoregulyatsii: fenomen, struktura $i$ funktsii $v$ proizvolnoy aktivnosti cheloveka [Individual style of selfregulation: phenomenon, structure and functions in the voluntary human activity]. Moscow: Nauka [in Russian].

15. Parsons, T. (1998). Sistema sovremennykh obshchestv [System of modern societies]. M. S. Kovaleva (Eds.). L. A. Sedova i A. D. Kovaleva (Trans.). Moscow: Aspekt Press [in Russian].

16. Prokhorov, A. O., Kulyhina, Y. V. (Eds.) (2007). Povsednevny koping: operatsionalnye sredstva i kompleksy samoregulyatsii psikhicheskikh sostoyanij subekta [Everyday coping: operational means and complexes of self-regulation of mental states of the subject]. Psikhologiya sovladayushchego povedeniya The psychology of coping behavior: Proceedings of the International Scientific and Practical Conference. (pp. 109-111). Kostroma: KSU [in Russian].

17. Petrovskiy, A. V., Yaroshevskiy, M. G. (Eds.). (1990). Psikhologicheskiy slovar [Psychological Dictionary]. Moscow [in Russian].

18. Stepanov, O. M. (2006) Psykholohichna entsyklopediia [Psychological encyclopedia]. Kyiv: Akademvydavnytstvo, 2006 [in Ukraine]. 
19. Rubinshtejn, S. L. (1997). Izbrannye filosofskopsikhologicheskie trudy [Selected philosophical and psychological works]. Moscow: Nauka [in Russian].

20. Rusalov, V. M. (1979). Biologicheskie osnovy individualnopsikhologicheskikh razlichiy [Biological bases of individual psychological differences]. Moscow: Nauka [in Russian].

21. Safonova, T. O. (2010). Urovnevye kharakteristiki samoregulyatsii lichnosti [Level characteristics of personality self-regulation]. Vestn. KeMGU - Vestn. KemSU, 3 (43), 100-106 [in Russian].
22. Seina,
S. A.
(2009).
Problema

mnogourovnevogo obespecheniya regulyacii povedeniya. Uchyonye zapiski [Problem of multilevel provision of behavior regulation. Scientific notes]. Ehlektronnyj nauchnyj zhurnal Kurskogo gosudarstvennogo universiteta - Electronic scientific journal of Kursk State University, 3, 122-128 [in Russian].

23. Teteruk, S. P. (2006) Formuvannia mekhanizmiv samorehuliatsii studentiv $\mathrm{V}$ inshomovnomu prostori [Formation of mechanisms of self-regulation of students in a foreign space]. Extended abstract of candidate's thesis. Kyiv [in Ukraine].

24. Schunk, Dale H.; Ertmer, Peggy A. Boekaerts,
Monique (Ed.); Pintrich, Paul R. (Ed.); Zeidner, Moshe (Ed). (2000). Self-regulation and academiclearning: Selfefficacy enhancing interventions. Handbook of selfregulation. San Diego, CA: Academic Press [in English].

25. Schraw, G., Crippen, K. J. \& Hartley, K. Res (2006). Promoting Self-Regulation in Science Education: Metacognition as Part of a Broader Perspective on Learning. Research in Science Education, Volume 36 (12), 111-139 [in English].

26. Sun, J. C-H. \& Rueda, R. (2012). Situational interest, computer selfefficacy and self-regulation: Their impact on student engagement in distance education. British Journal of Educational Technology. Volume 43 (2), 191-204 [in English].

27. Zabrucky, K. M. (2008). Metacognition and learning. In N. Salkind (Ed.), Encyclopedia of Educational Psychology. Thousand Oaks, CA: SAGE Publications, Inc. 673-676 [in English].

28. Zimmermann, B. (2008). Investigating SelfRegulation and Motivation: Historical Background, Methodological Developments, and Future Prospects. American Educational Research Journal, Volume 45 (1), 166-183 [in English].

Olena Denis, PhD student,

Department of General Pedagogy and Preschool Education, Drohobych Ivan Franko State Pedagogical University, 24, Ivana Franka Street, Drohobych, Ukraine

\section{SELF-REgUlATION OF PERSONALITY AS A PSYCHOLOGICAL AND PEDAGOGICAL PROBLEM}

The article reveals the essence of the concept of «self-regulation» and «self-regulation of personality». The current state of the problem self-regulation of personality is considered in the following positions: functions or properties of self-organized systems; complex multilevel systemic education; development of conscious self-regulation in activity and also this concept was studied in the aspect - "personality-activity". The current state of the problem of self-regulation of personality has been considered on the basis of existing scientific approaches such as subject-activity approach through understanding of conscious self-regulation of activity as a system-organized process of internal mental activity of man for initiation, construction, support and management of various types and forms of arbitrary activity that directly implements the achievement of goals that are accepted by man; structural-functional approach through self-regulation of arbitrary activity, which is characterized as the ability of the subject and as a process. Scientific concepts are of considerable interest for our study that have developed within the framework of: systemactivity concept of self-regulation of the state, in which self-regulation is characterized as an activity and as a state; the concept of individual style of self-regulation of arbitrary human activity; concepts that develop a view of selfregulation as a hierarchically organized system, which involves processes of different levels of individuality. A theoretical analysis of the problem of formation of the concept of «self-regulation of personality" in the scientific literature of various fields of knowledge has been done. A retrospective of scientific research on personality selfregulation is revealed: from understanding it as the most important explanatory principle in the system approach based on theories of functional systems as abilities and properties of the individual organism, to studying this category as a process and independent activity in functional state regulation. The basic conceptual positions, directions of researches and formation of the basic scientific concepts are considered. The basic conceptual positions and directions of researches in which the basic concepts from a researched problem are formulated are considered. Mechanisms of personality self-regulation such as self-esteem, level of one's own aspirations, self-control, reflection, self-stimulation are revealed.

Keywords: regulation, self-regulation, self-organization, self-regulation of personality. 